\title{
Dialect Levelling: A Case Study of Ìkàrẹ-Àkókó Dialect
}

\author{
Esther Olayinka Bamigbola, \\ Department of English Studies, Adekunle Ajasin University, \\ Àkùngbá-Àkókó, Nigeria. \\ bamigbolayinka@yahoo.com \\ Fadekemi Rukayat Umar \\ Adekunle Ajasin University, Àkùngbá-Àkókó, Ondo State, Nigeria \\ fadegoladipipo@gmail.com
}

DOI: $\underline{\text { http://doi.org/ 10.36892/ijlls.v3i3.640 }}$

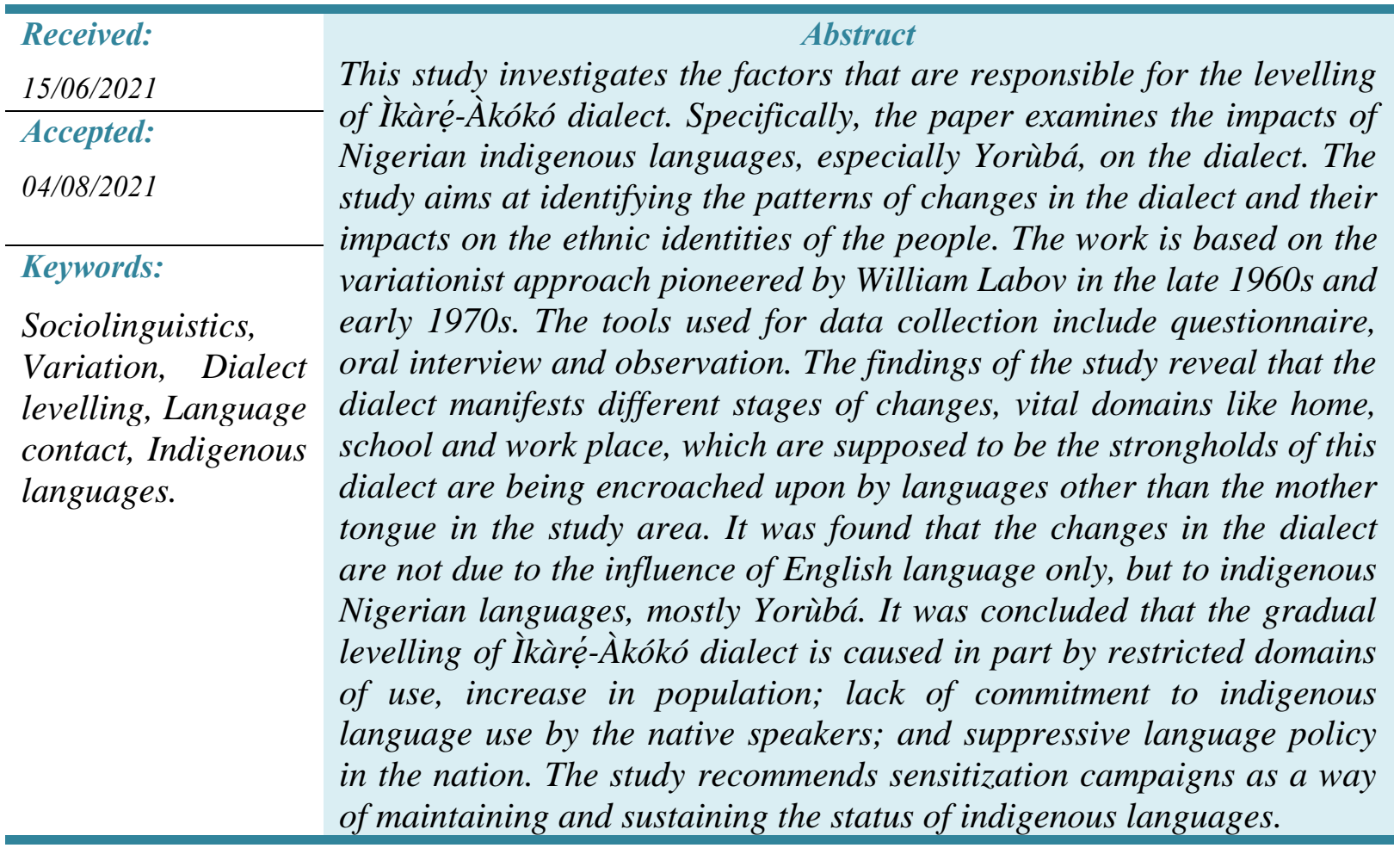

\section{INTRODUCTION}

The global challenge of language endangerment calls for more research attention on strategies to solve the problem. One of the approaches is to determine the status of minor languages so as to find the means of preserving them. Many researchers have observed that the rate at which languages are going into extinction is high, (Akinkurolere and Akinfenwa, 2018; Yunusa, 2020). This trend does not exclude Nigeria where about 516 languages are spoken (Crystal, 2000). In regions that are largely hetero-linguistic like Nigeria, the major languages tend to push the minor ones to the background, thereby restricting or limiting their domains of use. Apart from the majority/minority dichotomy, the language policy as embedded in the Nigerian Constitution does not, in practice, favour the small language groups, (Trudell, 2019). This study examines how language varieties differ between groups separated by certain social variables such as, age, status, setting, network and mobility. Also, 
the variables that limit the domains of use as well as those that hamper the competence of the native speakers in the dialect were studied.

Dialect levelling has been defined as the process by which structural variation in dialects is reduced (Hinskens, 1996, p.3). Dillard (1972, p.300) defines it as the process of eliminating prominent stereotypical features of differences between dialects". According to Lefebvre (1998, p.46), it is "the reduction of variation between dialects of the same language in situations where speakers of these dialects are brought together". Dialect levelling is said to be triggered by contact between dialects, often because of migration, and it has been observed in most languages with large numbers of speakers after the industrialization and the modernization of the area or areas in which they are spoken. It results in unique features of dialects being eliminated and "may occur over several generations until a stable compromise dialect develops" (Siegel, 1997, p.128; Hinskens, 1998, p.35). Such features could be lexical or syntactic. According to Kerswill and Trudgill (2005), dialect levelling is a selection of forms found in the previous dialect mix. In concrete terms, dialect levelling can also be defined as the elimination of distinctive features of a minority dialect in consequence of the increasing influence of a prestigious variety (Bassiouney, 2008).

Dialect levelling is a process of assimilation, mixture and merging of certain dialects, often by language standardization. Many of the affected dialects have either not been reduced to writing or do not have rich literature, which makes them unable to face the challenges of the modern time. In towns that receive many immigrants of different social classes, children are exposed at a young age to different dialects, and dialect levelling takes place unconsciously. Contact leading to dialect levelling can stem from geographical and social mobility, which bring together speakers from different regions and social levels. Adolescents can drive levelling as they familiarize their speech under the influence of their peers rather than their parents (Kerswill, 2001). In 20th century British English, dialect levelling was caused by social turmoil leading to larger social networks. Agricultural advancements caused movement of people from rural to urban areas and the construction of suburbs caused city dwellers to return to former rural areas. The World Wars brought women into the workforce and men into contact with more diverse backgrounds (Kerswill, 2001).

Dialect levelling has been shown to occur in mobile populations where there is a high level of dialect contact. In such areas, individuals regularly find themselves in face to face interaction with speakers of other varieties and in their efforts to accommodate, their interlocutors tend to avoid features that are unusual or markedly regional or which might lead to comprehension difficulties (Trudgill, 1986, p.25). Such individual acts of accommodation simulated throughout a population can lead to permanent language change as marked variants gradually disappear while the forms with the 'widest geographical and social usage' are retained (Trudgill, 1986, p.98). However, while first generation migrants will adapt in minor ways to their new linguistic environment, those that are nevertheless already adults who have passed the 'critical stage' of language acquisition (Lenneberg, 1967; Kerswill, 1996) are not likely to be able to make major grammatical and phonological changes to their speech.

Studies have reported the acquisition of 'easy features' and small changes in vowel quality as well as lexical and morpholexical borrowing in adult migrants (Kerswill, 1994), but it is their children, the second-generation migrants, who are central to the linguistic focusing that precedes the formation of a homogeneous variety. These children who at the pre-school stage normally acquire their parents' variety will go on to encounter a range of dialects as they start school and begin to expand their social contacts. During adolescence, a period when the need for independence from parents is accompanied by increasing loyalty to the peer group, strong pressure is employed by peers to conform to youth norms, including linguistic ones. It is in this age group, then that focusing can be expected to occur and 
features of the new levelled variety begin to emerge. According to Williams \& Kerswill (1999), factors that are said to be involved in dialect levelling include social mobility, migration within a country, geographical mobility and economic change.

It has been suggested that dialect levelling plays a role in the formation of creoles. It is responsible for standardizing the multiple language variants that are produced by the relexification of substrate languages with words from the lexifier language. Features that are not common to all of the bedrocks and so are different across the varieties of the emerging creole tend to be eliminated. The process begins when the speakers of the creole stop aiming the lexifier language and start aiming the relexified lexicons, that is, the early creole (Lefebvre, 1998, p.46). Dialect levelling in such a situation may not be complete, however. Variation that remains after dialect levelling may result in the reorganization of surviving variants to new functions, such as stylistic or social markers. Also, differences between bedrocks, including between dialects of a single bedrock, may not be levelled at all but instead persist, as differences between dialects of the creole (Trudgill, 1986).

A dialect may be levelled if it comes in contact with another language/dialect such that the latter tends to progressively assimilate the former. The issue of dialect contact and its attendant consequences such as bilingualism, linguistic interference, language shift, loss of linguistic purism have generated a great deal of linguistic research all over the world (Fakuade, 1995, p.1). Fakuade, Gambo and Bashir (2003), in their study "Language Shift from Mother Tongues towards Fulfulde in Adamawa State, Nigeria: Causes and Consequences", report that there is massive shift from the indigenous languages in these areas to Fulfulde, another indigenous language. Practically, the domains of use of the minor indigenous languages namely Bata, Bura, Bwatiye, Ghada, Gudu, Honna, Kanuri, Kilba, Lala, Yungur, Ngwaba and Mboi are being stifled by Hausa and Fulani. Fakuade et al., (2003) attribute this to factors of exposure and economic or social utility. Their study reveals that apart from the overbearing effect of exoglossic languages, there could be a situation where an indigenous language overrides another. According to them:

Minority languages in the study area are not only embattled, they are endangered as ethno-linguistic groups shift towards Fulfulde. These non-Fulfulde languages are declining as they lose their territorial base and are spoken by fewer and fewer monolinguals. Those who speak their Mother Tongues have become bilingual, finding that they must acquire Fulfulde, which is incipiently dominant. Fulfulde has intruded into more and more domains of life and assumed more and more functions among the different ethnic groups in the study area (Fakuade et al., 2003, p.311).

They conclude that if the trend continues unchecked, Fulfulde will replace some of the smaller languages in Adamawa State.

From observation as resident and indigene, Ìkàrẹ́-Àkókó dialect in Ondo State, Nigeria, manifests symptoms of levelling. No research has been carried out to examine this trend. In this connection, this study investigates the ethno-linguistic levelling of Ìkàrẹ-Àkókó dialect in Ondo State, Nigeria. This dialect belongs to the İkàrẹ-Àkókó phylum of the Yorùbá family (Comrie, 1990). The various factors that are accountable for the levelling of the dialect were investigated. The work also examines the degree of levelling with a view to determining the generational transmission of Ìkàrẹ-Àkókó dialect. Also, it attempts to ascertain whether the levelling of the dialect has impact on the ethnic identities in the study area; and suggests measures that can be taken to sustain the dialect.

\section{REVIEW OF RELATED LITERATURE}


Sociolinguistics is a discipline that seeks to determine, among other things, who speaks what variety of language, to whom and concerning what (Akintade and Adegbite 1999, p.5). It studies how language varieties differ between groups separated by certain social variables (e.g., ethnicity, religion, status, gender, level of education, age, etc.) and how creation and adherence to these rules is used to categorize individuals in social or socioeconomic classes. As the usage of a language varies from place to place, language usage also varies among social classes; and it is these sociolects that sociolinguistics studies. David (1986:164) opines that, the main task of sociolinguistics is to investigate variations across the following parameters: from one region to another, from one social group to another, from one age group to another and in some respects, from one sex to another. These are done with the aim of arriving at an understanding on how language operates across the social spectrum and thereby to obtain a deeper insight into the significance of variation for the field of language in general. Collins and Blair, quoting Fasold (1984) say that many sociolinguists have argued that language functions as a badge of social identity (Collins and Blair 1984, p.3).

Crucial to sociolinguistic analysis is the concept of prestige; certain speech habits are assigned a positive or a negative value, which is then applied to the speaker. This can operate on many levels. It can be realised on the level of the individual sound/phoneme, as Labov discovered in investigating pronunciation of the post-vocalic $/ r$ in the North-Eastern USA, or on the macro scale of language choice, as realised in the various diglossia that exist throughout the world, where Swiss-German/High German is perhaps most well-known. An important implication of the sociolinguistic theory is that speakers 'choose' a variety when making a speech act, whether consciously or subconsciously. Dittmar (1976:1), while explaining the empirical method of sociolinguistic investigation, views that sociolinguistics is concerned with analysing and explaining linguistic behaviours in social environment. It shares the problems of all sociolinguistic inquiry, the justification and precise formation of the problem, the representative of selection of informants, the problem of obtaining and eliciting data, choice of description category and the explanation of social behavior (Dittmar 1976:187).

According to Chambers (2003), studies of language variation and its correlation with sociological categories such as William Labov's 1963 paper "The social motivation of a sound change" led to the foundation of sociolinguistics as a subfield of linguistics. Although contemporary sociolinguistics includes other topics, language variation and change remains an important issue at the heart of the field. Studies in the field of sociolinguistics typically take a sample population and interview them, assessing the realization of certain sociolinguistic variables. According to Halliday (1978), stylistic variation and registers belong to language as system and regional and social varieties (regiolects, sociolects and accents) to language as institution. Although Halliday's division conveniently includes styles and registers within the study of language as system, it excludes dialectal variation. In fact, both models ultimately turn out to be reductionist, as none of them focuses on language as it is globally and actually used in real situations by multilectal speakers.

Language variation is a core concept in sociolinguistics and is also an important concept in this study. Sociolinguists do not only investigate whether this linguistic variation can be attributed to differences in the social characteristics of the speakers using the language, but also investigate whether elements of the surrounding linguistic context promote or inhibit the usage of certain structures. Contrary to many theories in linguistics which seek for categorical rules to explain the underlying principles in language, the variationist approach claims that language varies systematically in accordance with social characteristics of the speakers. The variationist sociolinguistics model assumes that the human language faculty accommodates and generates language variation, and that the workings of grammar may have a quantitative and non-categorical component. By means of the linguistic variable, 
one describes and analyses orderly heterogeneity in language use. The linguistic variable as a structural unit depends on the model of syntax one employs. It is argued that there exists a fairly direct connection between grammar and language use. A challenge for interdisciplinary accounts between the variationist sociolinguistic framework and formal syntactic theory is how to account for intra- and inter speaker variation (Wardhaugh, 2010).

When languages of varying sizes and statuses come in contact, there is the tendency for social, political, psychological and economic variables to make bilingualism imperative for speakers of minority languages, and this may lead to language shift and ultimately language death or language loss. For example, languages like Ake (Nassarawa State), Bakpiaka (Cross River), Butanci, Shau and Kudu-Camo (Bauchi), Chamba (Taraba), Sheni (Kaduna), Holma and Honta (Adamawa), and Sorko (Niger, Kwara and Kebbi) have been reported to have either gone into extinction or gone moribund (Fakuade, 1995; Ugwuoke, 1999). Further, Grimes, cited in Ejele (2002:122), identifies and lists a number of languages in Nigeria that are either extinct or nearly extinct. The extinct ones include: Ajawa (Ajanci) in Bauchi State, Auyokwa (Auyakawa, Awlaka) in Jigawa State, Basa-Kaduna (BasaGumna, Basa-Kuta) in Niger and Plateau States and Gano-Ningi. The nearly extinct ones include: Basa Kontagora in Niger State, Gana (Ganawa, Si-Gana) in Bauchi State, KuduCamo (Kuda-Chamo, Kudawa) and Taura (Takaya) in Bauchi State and Lufu in Taraba State.

Ìkàré-Àkókó dialect operates in the midst of a multilingual society. The survival of a language in a multilingual community depends on the true inward attitude of the owners towards the language (Fakuade, 2001). Many researches on language use and language attitude in Nigeria have focused on the contact of Nigerian languages with English. Of course the predictable result is the soaring tendency of English usurping the domains of the indigenous languages. The reason for this is not far-fetched. According to Munkaila and Haruna (2001, p.30), the ability to speak and to use the colonial languages gives people certain privileges; hence, attitude towards these languages is often positive. Going by the increased domains of English in Nigeria, and the resultant disuse, in certain areas, to which some of the indigenous languages have been put, scholars and observers have noticed that only a change of attitude can save Nigerian languages from total eclipse (Dada, 2007; Oyetade, 2005).

What appears to be a twist is in the attitude of speakers of indigenous languages to other indigenous languages. In other words, some Nigerian languages enjoy high prestige while some are held in low prestige. Oyetade (2005), reports that speakers of Ligau, an Akokoid language spoken in Ondo State, Nigeria, are abandoning it for Yorùbá. Blench (1998) also reports that a number of minor languages of the middle belt group in Nigeria have assimilated into Hausa. In the same vein, some of the minor languages in the southwest are giving way to Yorùbá. The trend does not spare Huba speakers who are becoming Bura. Speakers of Dobo have lost their language to Gbari as a result of migrations, and the Fali language of the Fali Plateau has given way to Ndoro, which is in retreat elsewhere (Blench, 1998, p.198). In Rivers State, Nigeria, it is reported that Obonoma speakers have linguistically and politically shifted to Izon (Otite, 1990). Factors such as trade, war and migration are some of the reasons for shift. But a major factor is attitude which is premised on the loss of faith in the affected languages by their speakers. In their assessment of what constitutes language attitude, Appel and Muysken (1987) note that the fact that languages are not only objective, socially neutral instruments for conveying meaning, but are linked up with the identities of social or ethnic groups has consequences for the social evaluation of, and the attitudes towards languages. They go further to say that, if there is a strong relation between language and identity, it will affect the attitudes of individuals towards these languages. 
Attitude towards languages is determined by many factors. On this premise, Appel and Muysken propose two theoretical approaches namely, the behaviourist and the mentalist views to study what determines attitudes towards language. The behaviorist approach, according to Appel and Muysken (1987, p.16), views attitude as the responses to languages in certain situations. The response may be influenced by the status of the speakers of a language. This could be negative or positive. However, the mentalist view considers attitude as an internal, mental state, which may give rise to certain forms of behaviour. It can be described as an intervening variable between a stimulus affecting a person and that person's response (Fasold, 1984, p.147).

\section{BACKGROUND INFORMATION ON THE CASE STUDY}

Through the natural phenomenon the Niger/Benue ' $Y$ ' shaped rivers, Nigeria is divided into three major areas i.e. North, West and East, corresponding with the three major language groups of Nigeria which include Hausa, Igbo and Yorùbá from North, South and East respectively. Beyond these three major language groups, there also exist at least more than four hundred indigenous language groups, with only nine prominent among them, into which translation will be needed when it comes to some national issues on language. These are Edo, Efik, Ijaw, Fulfulde, Igbo, Tiv, Kanuri, Yorùbá, and Hausa. There are also dialects within, and almost each and every ethnic group with different understanding in their languages, that is, not naturally intelligible to each other. Therefore, speakers of those dialects do not some time understand themselves though belonging to one linguistic group. In the Yorùbá ethnic group for example, an Àkókó Yorùbá speaker understands the Ibadan Yorùbá speaker, but the Àkókó Yorùbá speaker is not understood by the Ibadan Yorùbá speaker. Also Gombe Fulfulde speakers are understood by Adamawa Fulfulde speakers but the Gombe Fulfulde speakers do not understand the Adamawa Fulfulde speakers. In Edo and Delta states, the multicity of language is so obvious that the languages of people living in some kilometers are unintelligible to one another.

Ondo State in Nigeria was created on February 3, 1976, from the former Western State, with the state capital at Àkúrẹ. The state originally included the present Ekiti State, which was split off in 1996. It borders with Ekiti State to the north, Kogi State to the northeast, Edo State to the east, Delta State to the southeast, Ogun State to the southwest, and Osun State to the northwest and Atlantic Ocean to the south (Wikipedia, 2021). Ondo State is one of the multilingual states in Nigeria with dialect clusters of other languages apart from Yorùbá. The dialects are spread across the 18 local government areas of the state. Table 1 below shows the population distribution and languages spoken across the state by local government areas.

Table 1: Languages spoken in Ondo State and the population distribution by Local Government Areas

\begin{tabular}{|l|l|l|}
\hline \multicolumn{1}{|c|}{ LGA } & \multicolumn{1}{c|}{ POPULATION } & \multicolumn{1}{c|}{ LANGUAGES/DIALECTS SPOKEN } \\
\hline Àkókó North-West & 213,792 & Àhàn; Akpes; Arigidi; Àyèré \\
\hline Àkókó North-East & 175,409 & $\begin{array}{l}\text { İkàré-Àkókó; Akpes; Arigidi; Emai-Iuleha-Ora; } \\
\text { Àyèré }\end{array}$ \\
\hline Àkókó South-East & 82,426 & Uhalmi \\
\hline Àkókó South-West & 229,486 & Emai-Iuleha-Ora \\
\hline Ose & 144,901 & Edo; Emai-Iuleha-Ora \\
\hline Ọ̀wọ & 222,262 & Òwọ̀ \\
\hline Àkúrẹ́ North & 131,587 & Àkúrẹ́ \\
\hline
\end{tabular}




\begin{tabular}{|l|l|l|}
\hline \multicolumn{1}{|c|}{ LGA } & \multicolumn{1}{|c|}{ POPULATION } & \multicolumn{1}{c|}{ LANGUAGES/DIALECTS SPOKEN } \\
\hline Àkúrẹ́ South & 353,211 & Àkúrẹ́ \\
\hline Ìfẹ́dọ̀rẹ́ & 176,327 & Àkúrẹ \\
\hline Ilẹ̀ Olúji & 172,870 & Òndó \\
\hline Ondo West & 283,672 & Òndó \\
\hline Ondo East & 74,758 & Òndó \\
\hline Ìdànrè & 129,024 & Òndó \\
\hline Odigbo & 230,351 & İkálẹ, Òndó \\
\hline Okitipupa & 233,565 & İkálẹ, Edo \\
\hline Irele & 145,166 & Edo, Ìkálẹ \\
\hline Ẹsẹ̀ Odò & 154,978 & Izon, apoi \\
\hline Ìlàje & 290,615 & Ìlàje \\
\hline Total & $\mathbf{3 , 4 4 4 , 4 0 0}$ & \\
\hline
\end{tabular}

The dialects in Ondo State are at various stages of development with majority existing only in oral form and have not been committed to writing (Emenanjo, 1985). The domains of use of these dialects range from home to larger environments like school, marketplace, playground and the media. Some of these dialects are being stifled as a result of pressure, largely from major languages. Àkókó land of Ò̀ndó State is presently comprised of four local government areas which include Àkókó North-East, Àkókó North-West, ÀkókóSouth East and Àkókó South-West. The major towns/villages in Àkókó land include İkàré, Ùgbè̀, Akùnnù, Ìkákùmọ̀, Ìbòròpa, Ișè, Àúga in Àkókó North-East; Àjọwá, Oyín, Gèdègéde, Ìbáràmù, Ìkáràmù, Ìgásí, Esé, Òkè-Àgbè, Arigidi, İrùn, Ọgbàgì in Àkókó North-West; Ìpèsì, İfira, Șósan, İșùà, Ẹpìnmì in Àkókó South-East and Ìkùn, Àkùngbá, Ọ̀bà, Súparè and Ộkà in Àkókó South-West. Each of these towns is linguistically and politically independent. Olumuyiwa and Oshodi (2012) quoting Williamson \& Blench (2000, p.31) reported that the speech forms in Àkókó land have been classified under the Yoruboid, Edoid and Àkókóid of the YEAI sub group of West Benue-Congo language family.

Ìkàrẹ is centrally located within the heart of the Àkókó North East Local Government Area of Ondo State, with a landmass of approximately one hundred and fifty two kilometers square $\left(152 \mathrm{~km}^{2}\right)$. The town is the headquarters of Àkókó North East Local Government Area. Ìkàré is one of the prominent towns of the ancient period that refer to Ilé-Ifẹ̀ as their cradle. Ìkàré-Àkókó has witnessed a great demographic growth in recent years due to the influx of immigrants for some socio-economic reasons which include the relocation of the former Ondo State University (now Adekunle Ajasin University) to Àkùngbá-Àkókó which is about 3 kilometers from İkàrẹ-Àkókó. The 1963 census puts the population of İkàrẹ at 62,000, while the 1991 head-count gave İkàrẹ-Àkókó a population of 103,501, and the 2006 census puts the population at 126,625 inhabitants (FBS, 2007).

The indigenous people of Ìkàré-Àkókó speak Ìkàré dialect but they understand the wider Yorùbá language. There are a considerable number of people from other parts of the country in Ìkàrẹ such as Hausas, Igbos, Ebiras, Nupes and so on. The people of Ìkàrẹ́ are mainly farmers. They are known for planting cash crops especially Cocoa, Kolanut, Coffee, and Cotton. The closeness of Ìkàrẹ to other towns outside Ondo State also makes it possible for people to come from different parts of the country to trade. There is an influx of traders from the North who trade in kolanuts and the Ibos from the East are dealers in wares, electronics and automobile accessories. This has contributed to the growth in population of 
the town in making it a modern city. There are also various tourist attractions and places of interest in Ìkàrẹ such as the Owá-Ale Hill and Omi-Atan Spring, Ojú-Òyò, Agólómolódò Mausoleum, Orimolade Mercy Land and Mausoleum and Aringíyà Brook.

\section{THEORETICAL FRAMEWORK}

Variationist sociolinguistics is an approach to quantitative studies of linguistic variation with the central belief that the alternative forms which can be found in all languages do not occur randomly but influenced either by external social factors, internal linguistic factors, or both. According to Labov (1972), "internal structure pressures and the sociolinguistic pressures act in systematic alternation in the mechanism of linguistic change" (Labov, 1972, p.181). An aspect of linguistic variation is that within a speech community, speakers who belong to different age groups, social classes, ethnic groups, and genders show systematic differences in the way they talk. The concern of variationist sociolinguistics is to investigate the relationship between the use of language and these other factors - age, social class, ethnicity, gender, occupation, etc. Labov's method was employed for this study. His principles and assumptions as summarized by Hickey (2010) are as follows:

1. Linguistic variation is socially determined.

2. Speakers are in a double bind: On the one hand, they show identification with their locality through the use of a local variety of language. On the other hand, they aspire to social acceptability and hence in their speech they move towards the standard of their area.

3. Surreptitious interview methods mean that the observer's paradox is minimized.

\section{METHODOLOGY}

A sociolinguistic approach was used for this study. Specifically, Labov's variationist sociolinguistic method was employed. Oral interview, observation and questionnaire were employed for data collection. In order to gather basic data on the language situation in ÌkàrẹÀkókó, a survey of some areas like school, market, office, motor park and other public places in the study area was carried out with a view to assessing the language use and language attitude of the people. Given the fear usually anticipated by speakers of languages when approached by researchers, the assistance of a serving principal in one of the secondary schools in Ìkàré-Àkókó was sought. His familiarity with the study area and the people helped to gain the confidence of the respondents during the gathering of information. However, resistance could not be totally ruled out. The questionnaire designed for data collection is as contained in the Appendix. The questionnaire was written in English while the illiterates were guided by interpreters. The serving principal and another research assistant served as interpreters to some uneducated respondents by interpreting the questions to them and writing down their responses. They also made sure that copies of the questionnaire were in safe hands and ensured that all the copies were filled and returned. Data gathering for the study was carried out in the six wards that constitute Ìkàrẹ-Àkókó: İlèpa, İ̀ádò, İyò-méta, Òrún-ùn, Oyinmò and Àrúwá. The questionnaire used was modeled after Fakuade's (1995) version used in the study of language contact and language conflict in Taraba State, Nigeria. The distribution of the questionnaire covered all categories: the young, the old, the educated, the uneducated, males and females. The selected respondents are representative of the different age groups, status and classes of people in the study area.

Two hundred copies of the questionnaire were distributed and all the copies were completed and returned. The study also made use of what Fakuade (1995, p.52) calls 'exchange technique'. This, according to him, 'is a technique that requires an investigator to reward his informants if he wants to have their attention for a long time'. The administration process was monitored by the researchers to ensure fairness and effectiveness. The questionnaire was divided into three parts: Section A was directed at gathering information 
on the respondents' personal details, Section B focused on language use in the different domains, while section $\mathrm{C}$ focused on language attitude. The statistical method used for the analysis was simple percentage. Structured and unstructured oral interviews were also conducted to complement information gathered through the administration of the questionnaire.

The oral interview involved five elders who were above 75 years of age and five young adults between the ages of 35 and 50 years. Both prepared and spontaneous questions were used. The oral interview was conducted between September 2016 and February 2017. All the people interviewed are natives of İkàrẹ-Àkókó. A cell phone was used to record the conversations. A woman of 78 years old who lives at Iku, one of the quarters in İkàrẹ-Àkókó was interviewed. Another man who was 114 years old and the 'Opòn' (the oldest person) of Òkojà (now late as at the time of writing this paper) was also interviewed. The man provided reliable information about the history, economic and social-political profile of İkàré. This interaction also enabled the researchers to observe how the elders use the dialect. The researchers also interacted with some youths who are grandchildren to the man. Many differences were observed in the way the old man used the dialect and how the grandchildren use it. Important personalities and opinion leaders from different subdivisions of the study area were also interviewed. Through this, it was possible to have direct contact with the people and to have a good knowledge of the attitude of the people toward their dialect. The oral questions were drawn from the items in the questionnaire.

Participant observation was also employed as a vital instrument in this study. This technique made it possible to record natural and authentic data on the language use of the speakers of the dialect. Through this, the investigator watched and observed language use in market places, canteens, schools, relaxation centers, and other public places. Field assistants were also of tremendous help during this period. Information obtained through observation was used to complement and validate those obtained through questionnaire and interview. Frequency counts and simple percentage were used to analyze the patterns of levelling vis-àvis the domains of use and other variables considered.

\section{RESULT AND DISCUSSION}

\subsection{Analysis of Responses to Questionnaire Items, Oral interview Questions and Language Behaviours Observed}

The responses to items in the questionnaire, oral interview questions and the observed language behaviours constitute the result for this study which are analysed below.

Table 1: Classification of respondents by age

\begin{tabular}{|l|c|c|}
\hline AGE RANGE & NO. OF RESPONDENTS & PERCENTAGE \\
\hline $10-20$ years & 58 & 29 \\
\hline $21-40$ years & 73 & 36.5 \\
\hline $41-60$ years & 62 & 31 \\
\hline 61 years and above & 7 & 3.5 \\
\hline Total & $\mathbf{2 0 0}$ & $\mathbf{1 0 0}$ \\
\hline
\end{tabular}

From the result in table 1, 58 of the respondents, making $29 \%$ are between age 10 to 20 years, 73 making $36.5 \%$ are between 21 to 40 years, 62 making $31 \%$ are between 41 to 60 years while 7 making $3.5 \%$ are above sixty-one years old. This shows that the number of youths is higher than adults among the respondents. 
Table 2: Classification of respondents by sex

\begin{tabular}{|l|c|c|}
\hline SEX & FREQUENCY & PERCENTAGE \\
\hline Male & 67 & 33.5 \\
\hline Female & 133 & 66.5 \\
\hline Total & $\mathbf{2 0 0}$ & $\mathbf{1 0 0}$ \\
\hline
\end{tabular}

The above result shows that sixty -seven, making $33.5 \%$ of the respondents are males while one hundred and thirty three, making $66.5 \%$ are females. In most of the offices and places visited, there were more women than men.

Table 3: Academic qualifications of respondents

\begin{tabular}{|l|c|c|}
\hline ACADEMIC QUALIFICATION & NO. OF RESPONDENTS & PERCENTAGE \\
\hline Primary School & 13 & 6.5 \\
\hline Secondary School Certificate (SSC) & 38 & 19 \\
\hline NCE/OND & 41 & 21.5 \\
\hline Bachelor Degree/HND & 65 & 32.5 \\
\hline Masters Degree & 23 & 11.5 \\
\hline PhD & 6 & 3 \\
\hline Uneducated & 14 & 7 \\
\hline Total & $\mathbf{2 0 0}$ & $\mathbf{1 0 0}$ \\
\hline
\end{tabular}

The result shows that 13 making 6.5\% are holders of Primary School certificate, 38 making $19 \%$ are holders of secondary school certificate, 41 making $21.5 \%$ are holders of Ordinary National Diploma certificate or Nigeria Certificate in Education, 65 making 32.5\% of the respondents are holders of Bachelor Degree or Higher National Diploma (HND) certificates, 23 making 11.5\% are Masters Degree holders, 6 making 3\% have $\mathrm{PhD}$ and 14 making $7 \%$ are uneducated. This trend is an indication that the people of Ìkàrẹ-Àkókó value education.

Table 4: Summary of responses to question on what language the respondents acquired first

\begin{tabular}{|l|c|c|}
\hline LANGUAGE & NO. OF RESPONDENTS & PERCENTAGE \\
\hline Yorùbá & 137 & 68.5 \\
\hline English & 3 & 1.5 \\
\hline İkàrẹ́ dialect & 58 & 29 \\
\hline Igbo & 2 & 1 \\
\hline Total & $\mathbf{2 0 0}$ & $\mathbf{1 0 0}$ \\
\hline
\end{tabular}

From the result in the above table, 137 making $68.5 \%$ of the respondents acquired and spoke Yorùbá as their first language, 3 making 1.5\% indicated that English was the first language they spoke in their childhood, 58 making $29 \%$ acquired İkàré-Àkókó dialect as their first language, and 2 which constitute $1 \%$ acquired Igbo as their first language. Majority of the respondents claimed that they speak Yorùbá because it is the language of wider communication in the area. Some of the respondents are of the opinion that their dialect can best be learnt at home (that is, in the first language environment or within the family), therefore, Ìkàrẹ-Àkókó dialect was introduced to their children as their first language. A good number of the respondents still respects and appreciates their dialect.

Table 5: Summary of responses to question on whether the respondents can still speak the languages they acquired first 


\begin{tabular}{|l|c|c|}
\hline RESPONSE & NO. OF RESPONDENTS & PERCENTAGE \\
\hline Yes & 167 & 83.5 \\
\hline No & 33 & 16.5 \\
\hline Total & $\mathbf{2 0 0}$ & $\mathbf{1 0 0}$ \\
\hline
\end{tabular}

As shown in Table 5 above, 167 making $83.5 \%$ of the respondents can still speak the language they acquired first while 33 making $16.5 \%$ can no longer speak their L1. This shows that many of the respondents appreciate their mother tongue and still hold on to it.

Table 6: Summary of responses to question on whether the language they acquired first is the one they speak best

\begin{tabular}{|l|c|c|}
\hline RESPONSE & NO. OF RESPONDENTS & PERCENTAGE \\
\hline Yes & 87 & 43.5 \\
\hline No & 60 & 30 \\
\hline No Response & 53 & 26.5 \\
\hline Total & $\mathbf{2 0 0}$ & $\mathbf{1 0 0}$ \\
\hline
\end{tabular}

From the result on table 6,87 making $43.5 \%$ of the respondents confirmed that the language they acquired first is still the one they speak best, while 60 making $30 \%$ indicated that the language they acquired first is not the one they can speak best. Fifty-three which constitute $26.5 \%$ did not give any response to the question. It was observed that Yorùbá Language has gained prominence in İkàrẹ́-Àkókó land. Majority of the respondents were introduced to Yorùbá as their first language and it still remains the language they speak best.

Table 7: Summary of responses to the question on the languages the respondents can speak better than those they acquired first

\begin{tabular}{|l|c|c|}
\hline LANGUAGE & NO. OF RESPONDENTS & PERCENTAGE \\
\hline Yorùbá & 116 & 58 \\
\hline English & 12 & 6 \\
\hline Ìkàré dialect & 40 & 20 \\
\hline No Response & 32 & 16 \\
\hline Total & $\mathbf{2 0 0}$ & $\mathbf{1 0 0}$ \\
\hline
\end{tabular}

The result on table 7 above shows that majority of the respondents can no longer speak their first language fluently. One hundred sixteen making 58\% of the respondents speak Yorùbá, 12 making 6\% of the respondents speak English, 40 making 20\% indicated that they speak their dialect best while 32 making $16 \%$ did not give any response to the question. It was observed that only the elderly people speak the dialect fluently while the younger ones code-switch or code-mix with Yorùbá when speaking the dialect.

Table 8: Summary of responses to the question on other language(s) the respondents can speak very well

\begin{tabular}{|l|c|c|}
\hline LANGUAGE & NO. OF RESPONDENTS & PERCENTAGE \\
\hline Yorùbá & 77 & 38.5 \\
\hline English & 90 & 45 \\
\hline Ìkàré dialect & 26 & 13 \\
\hline No Response & 7 & 3.5 \\
\hline Total & $\mathbf{2 0 0}$ & $\mathbf{1 0 0}$ \\
\hline
\end{tabular}

From the result, 77 making 38.5\% of the respondents speak Yorùbá language fluently, 90 which constitute $45 \%$ indicated that they speak English very well. Only 26 making $13 \%$ of the respondents chose İkàré-Àkókó dialect as the language they can speak very well, while 7 making $3.5 \%$ did not indicate what language they speak very well. Those 
that indicated that Ìkàrẹ-Àkókó dialect is the language they speak very well are mostly elders who wish to preserve and pass on the dialect to the next generation. They are those who uphold the dialect and enlighten the youths on how to value the dialect.

Table 9: Summary of responses to question on which language(s) the respondents understand, speak and use frequently

\begin{tabular}{|l|c|c|}
\hline LANGUAGE & NO. OF RESPONDENTS & PERCENTAGE \\
\hline Yorùbá & 53 & 26.5 \\
\hline English & 122 & 61 \\
\hline İkàré dialect & 14 & 7 \\
\hline Pidgin & 2 & 1 \\
\hline French & 1 & 0.5 \\
\hline No Response & 8 & 4 \\
\hline Total & $\mathbf{2 0 0}$ & $\mathbf{1 0 0}$ \\
\hline
\end{tabular}

Fifty-three, making $26.5 \%$ chose Yorùbá as the language they frequently use, 122 making $66 \%$ chose English as the language they use mostly in their places of work and schools. Fourteen, making $7 \%$ of the respondents indicated that they use İkàré-Àkókó dialect frequently while 2 making $1 \%$ of the respondents indicated that they speak pidgin. These people are Hausas who cannot speak English fluently. From observation, the only person who claims to speak French is a student who only knows how to greet in French but has no advanced knowledge of the language. Eight making 4\% of the respondents did not choose any answer to the question probably because they speak their dialect and Yorùbá language interchangeably.

Table 10: Summary of responses to the question on other language(s) the respondents understand but use less frequency

\begin{tabular}{|l|c|c|}
\hline LANGUAGE & NO. OF RESPONDENTS & PERCENTAGE \\
\hline Yorùbá & 145 & 72.5 \\
\hline English & 35 & 17.5 \\
\hline No Response & 20 & 10 \\
\hline Total & $\mathbf{2 0 0}$ & $\mathbf{1 0 0}$ \\
\hline
\end{tabular}

From the result in Table 10, 145 making $72.5 \%$ of the respondents chose Yorùbá language while 35 making 17.5\% chose English. Those that chose English are mostly civil servants and the semi literates who want their children to speak English at all cost. Twenty making $10 \%$ of the respondents did not indicate any language.

Table 11: Summary of responses to question on whether the respondents can read or not

\begin{tabular}{|l|c|c|}
\hline RESPONSE & NO. OF RESPONDENTS & PERCETAGE \\
\hline Yes & 162 & 81 \\
\hline No & 24 & 12 \\
\hline No Response & 14 & 7 \\
\hline Total & $\mathbf{2 0 0}$ & $\mathbf{1 0 0}$ \\
\hline
\end{tabular}

From the result in the above table, 162 making $81 \%$ of the respondents indicated that they can read, 24 making 12\% cannot read and fourteen, constituting 7\% did not give any answer to the question. This is an indication that majority of the people are educated.

Table 12: Summary of responses to the question on whether the respondents can write or not 


\begin{tabular}{|l|c|c|}
\hline RESPONSE & NO. OF RESPONDENTS & PERCETAGE \\
\hline Yes & 159 & 79.5 \\
\hline No & 24 & 12 \\
\hline No Response & 17 & 8.5 \\
\hline Total & $\mathbf{2 0 0}$ & $\mathbf{1 0 0}$ \\
\hline
\end{tabular}

The result shows that 159 making $79.5 \%$ of the respondents can write. Among those who can write very well are students and civil servants like teachers and retired bankers. However, it was discovered during the administration of questionnaire that some, who claim they can write, could not actually write very well. Some of them later requested for assistance to fill the questionnaire because they cannot write very well or have bad handwriting. Twenty four, making $12 \%$ of the respondents claimed they cannot write at all because they are not educated. Seventeen, which constitute $8.5 \%$ of the respondents did not respond to the question but also confessed clearly that they cannot write even their names. The information on ability of the respondents to read or write is with regard to English, Yorùbá and other languages.

Table 13: Summary of responses to question on language(s) spoken at home to family members

\begin{tabular}{|l|c|c|c|c|c|c|c|c|c|c|}
\hline Language & $\begin{array}{c}\text { Wife or } \\
\text { Husband }\end{array}$ & $\mathbf{\%}$ & Parents & $\mathbf{\%}$ & Children & $\boldsymbol{\%}$ & Friends & \% & Sibling & \% \\
\hline Yorùbá & 74 & 37 & 95 & 47.5 & 57 & 28.5 & 62 & 31 & 125 & 62.5 \\
\hline English & 25 & 12.5 & 16 & 8 & 14 & 7 & 43 & 21.5 & 27 & 13.5 \\
\hline $\begin{array}{l}\text { İkàrẹ́ } \\
\text { Dialect }\end{array}$ & 21 & 10.5 & 61 & 30.5 & 20 & 10 & 7 & 3.5 & 40 & 20 \\
\hline $\begin{array}{l}\text { No } \\
\text { Response }\end{array}$ & 80 & 40 & 28 & 14 & 109 & 54.5 & 88 & 44 & 8 & 4 \\
\hline Total & $\mathbf{2 0 0}$ & $\mathbf{1 0 0}$ & $\mathbf{2 0 0}$ & $\mathbf{1 0 0}$ & $\mathbf{2 0 0}$ & $\mathbf{1 0 0}$ & $\mathbf{2 0 0}$ & $\mathbf{1 0 0}$ & $\mathbf{2 0 0}$ & $\mathbf{1 0 0}$ \\
\hline
\end{tabular}

From the result in the above table 74 of the respondents who are married, constituting $37 \%$ communicate with their spouses in Yorùbá language while 25 making $12.5 \%$ use English language when communicating with their spouses. Twenty-one making $10.5 \%$ of the respondents who are married use İkàrẹ-Àkókó dialect when communicating with their spouses. Eighty making $44 \%$ of the respondents did not indicate any language. These are students, spinsters and bachelors who are not yet married. On language spoken to parents, 95 constituting $47.5 \%$ of the respondents who are children use Yorùbá when communicating with their parents 16 making 8\% use English to communicate with their parents, 61 making $30.5 \%$ who are children use İkàré-Àkókó dialect to with their parents. Most of these are children whose parents are illiterates and those whose parents have made the dialect compulsory as a medium of communication at home. Also, some adults who have mothers or grandmothers and grandfathers communicate with their parents in Îkàrẹ dialect. On language spoken to children by parents, 57 making $28.5 \%$ who are parents communicate with their children in Yorùbá language, 14 making 7\% use English language, 20 making 10\% use Ìkàrẹ́Àkókó, while 109 making 55.5\% gave no response because some of the respondents are not yet parents. This category of people who are students, spinsters and bachelors when interviewed, said they are proud of their dialect and will uphold it till death. On language spoken with friends, 62 making $31 \%$ chose Yorùbá, 43 making 21.5\% chose English, 7 making 3.5\% chose Ìkàrẹ-Àkókó dialect claiming that all their friends are from their town, 88 making $44 \%$ did not indicate any language because some said their wives and children are their friends and others said they have no friends. Some of the respondents said the choice of language they use when communicating with friends depend on the tribe of the friends. On 
the language spoken with siblings, 125 making $62.5 \%$ indicated that they communicate with their siblings using Yorùbá language, 27 making 13.5\% chose English, 40 making 20\% indicated that they use İkàrẹ-Àkókó dialect but said they sometimes switch to Yorùbá, English or other languages. One of the respondents said whenever they are discussing and their grandmother is around, they switch to English if they don't want her to know what they are discussing. Eight, making 4\% did not indicate any language.

From the result, it is obvious that Yorùbá language has taken the place of ÌkàrẹÀkókó dialect in many homes. It was observed that some educated couples communicate in English so as to encourage their children to speak English language. Even some semieducated parents who cannot speak correct English force themselves to speak either English or pidgin. Only few of the respondents who are married use İkàré-Àkókó dialect as the medium of communication in their homes. Some of these people are educated couples who value and want to preserve the dialect at all cost. This group chooses to speak the dialect for the sake of their children. It was found that the dialect was not introduced to some children at all. One of the women said her children must always speak English. A man lamented that he could not speak English but he will want his children to speak it by all means. The few people, who communicate with their parents in Ìkàrẹ dialect, are children whose parents are illiterates and those whose parents have made the dialect compulsory as a medium of communication at home. It was observed that people code-switch from the dialect to even English language. During the interaction, a man said at home, he uses İkàrẹ-Àkókó dialect to communicate with his children but when they are communicating outside, he uses English.

Table 14: Summary of responses to the question on language(s) the respondents speak to colleagues at work

\begin{tabular}{|l|c|c|c|c|c|c|c|c|}
\hline Language & Employer & \% & Subordinate & $\boldsymbol{\%}$ & Equal & \% & Customers & \% \\
\hline Yorùbá & 47 & 23.5 & 72 & 36 & 102 & 51 & 106 & 53 \\
\hline English & 94 & 47 & 65 & 32.5 & 26 & 13 & 52 & 26 \\
\hline $\begin{array}{l}\text { İkàrẹ́ } \\
\text { Dialect }\end{array}$ & 9 & 4.5 & 9 & 4.5 & 18 & 9 & 5 & 2.5 \\
\hline No Resp. & 50 & 25 & 54 & 27 & 54 & 27 & 37 & 18.5 \\
\hline Total & $\mathbf{2 0 0}$ & $\mathbf{1 0 0}$ & $\mathbf{2 0 0}$ & $\mathbf{1 0 0}$ & $\mathbf{2 0 0}$ & $\mathbf{1 0 0}$ & $\mathbf{2 0 0}$ & $\mathbf{1 0 0}$ \\
\hline
\end{tabular}

The result on table 14 above shows that 47 making $23.5 \%$ of the respondents communicate with their employers in Yorùbá language. These include apprentices, salesgirls or sales boys etc. while 94 making $47 \%$ use English as the language of communication with their employers. Some of these are civil servants like teachers and bank workers. This is because English is the official language in Nigeria. Nine, making 4.5\% use their dialect, 50 which constitute $25 \%$ of the respondents did not indicate any language because they are unemployed. These include students and those that are unemployed. On languages spoken to subordinates, 72 making $36 \%$ of the respondents speak Yorùbá to the junior staff most especially at the local government secretariat, school staffrooms, police offices, etc. Yorùbá serves as medium of communication between the salesgirls and their bosses. Most of the bosses in fashion designers' shops, mechanic workshops, and other trade centres use Yorùbá to communicate with their apprentices especially those that are not from their community who do not understand Ìkàrẹ-Àkókó dialect. Sixty five, making 32.5\% use both English and Yorùbá depending on the language they find convenient and the context of their discussion, 9 making $4.5 \%$ of the respondents chose Ìkàré-Àkókó dialect as the language of communication with their subordinates. A teacher during the interaction sessions said he could speak his language anywhere he comes in contact with someone who can understand 
him. Fifty four, making $27 \%$ of the respondents did not indicate any language because they are not employed and do not have any boss or subordinate. On language spoken with equals at work, 102 making $51 \%$ of the respondents communicate with their colleagues in Yorùbá language, 26 making 13\% make use of both English and Yorùbá, 18 making 9\% use İkàréÀkókó dialect to communicate with their equals at work and 54 making $27 \%$ did not indicate any language because they are unemployed. On language spoken with customers, the result shows that 106 making 53\% use Yorùbá language, 52 making 26\% indicated that they use English and pidgin. It was observed that whenever a Hausa or an Igbo speaker or trader wants to communicate with an İkàrẹ trader, he/she will try to speak Yorùbá as much as he/she can. Five, making $2.5 \%$ of the respondents said that they speak their dialect irrespective of what language group the customer belongs while 37 making $18.5 \%$ did not select any language. The result indicates that Yorùbá is the language mostly used by traders in İkàré-Àkókó. Even in work places when communicating with subordinates and equals, the use of Yorùbá language is mostly employed. English language, being the language of wider communication, also has a high number of speakers in all the domains examined.

Table 15: Summary of responses to the question on whether there are places apart from home and place of work where the respondents spend much of their time and if so, the language they use there

\begin{tabular}{|l|c|c|}
\hline RESPONSE & NO. OF RESPONDENTS & PERCETAGE \% \\
\hline Yes & 115 & 57.5 \\
\hline No & 52 & 26 \\
\hline No Response & 33 & 16.5 \\
\hline Total & $\mathbf{2 0 0}$ & $\mathbf{1 0 0}$ \\
\hline
\end{tabular}

The result in table 15 above shows that 115 making $57.5 \%$ of the respondents do not go home directly after work. Some women and youths said they play with their friends before going home. Some of the men said they chat with their co-workers in the office after work. Some said they need to meet some friends or business partners to discuss business while some go to their shops after office hours. Some attend evening services in their various churches after work. The language used depends on the company of friends and meetings they attend. Most of the respondents said Yorùbá is the language they use because it helps them to express themselves freely. Only few whose friends are Igbo said they communicate with them in English or Pidgin. Fifty two, making 26\% of the respondents do not visit other places office hours; they go home immediately after work. More than half of the respondents in this category said İkàrẹ dialect is their medium of communication at home. Most of the respondents in this category are youths who help their parents at home after school hours and women who have to prepare lunch for members of their families. Some of them are civil servants like teachers while some are shop attendants. Thirty three, making $16.5 \%$ did not respond to the question because they are unemployed.

\subsection{Some Linguistic Changes Observed in İkàrẹ́-Àkókó Dialect}

The table below shows the differences in the way some words are used by the elders and youths in İkàrẹ-Àkókó dialect.

Table 16: List of words as used by elders and youths in Ìkàrẹe-Àkókó dialect

\begin{tabular}{|c|l|l|l|l|}
\hline S/N & \multicolumn{1}{|c|}{ Elders } & \multicolumn{1}{|c|}{ Youths } & $\begin{array}{c}\text { Standard Yorùbá } \\
\text { Equivalent }\end{array}$ & \multicolumn{1}{|c|}{ English Gloss } \\
\hline 1. & Úurùnmò̀bà & Òórùnmọ̀bà & Efirin & Scent leaf \\
\hline 2. & Í́ró & İ́ró & Ėgúsí & Melon \\
\hline 3. & Ùgbẹ́n & İgbé́n & İgbín & Snail \\
\hline 4. & Urẹn & Irẹn & Irin & Iron \\
\hline
\end{tabular}




\begin{tabular}{|c|c|c|c|c|}
\hline 5. & Ògìdànrun & Òru & Ògànjọ́ Òru & Midnight \\
\hline 6. & Uugú & Apèrè̀ & Apẹrè̀ & Basket \\
\hline 7. & Ééra & Ewé & Ewé & Leaf \\
\hline 8. & Òpòtó & Òpòló & Òpòloó & Toad \\
\hline 9. & Umẹ́ndan & Sìsí & Òdóbìnrín & Girl \\
\hline 10. & Alùwẹ & Ibalùwẹ & Balùwè & Bathroom \\
\hline 11. & Èkété & Òkété & Ehoro & Rabbit \\
\hline 12. & Usẹ́n & Òbe & Òbe & Knife \\
\hline 13. & Apepe & Àjà̀ & Àjà & Wall Hanger \\
\hline 14. & Ùnàmùsu & Òkù & İdí & Anus \\
\hline 15. & Ashialá & Òrun ilá & Òrúnlá & Dry Okra \\
\hline 16. & Òkòtómú & İkèté & Epo & Burnt Palm Oil \\
\hline 17. & İlèmú & Osàn & Osàn & Orange \\
\hline 18. & İdun & Òdè̀ & Dìndìnrìn/Ọdẹ & Nonentity \\
\hline 19. & E kèèyé & Káàsánmọmọ́ & E káàsán mà & Good afternoon ma \\
\hline 20. & E kààbá & Káàsánbàbá & E káàsánsà & Good afternoon sir \\
\hline 21. & Amùsuà & Ojúkòkòrò & Ojúkòkòrò & Covetous \\
\hline 22. & Ugúroyìn & Ugúnugú/búrẹ́wà & Buréwà & Ugly \\
\hline 23. & Akólagbà & Kọrò̀ & Àbújá & Short cut \\
\hline 24. & Itapẹ́n & Kòkòrò & Kòkòrò & Insect \\
\hline 25. & Ohun & Àjegbáyo & Májèlé & Poison \\
\hline 26. & Àpólèèlí & Ilèèélè & Ilẹélè & Bare floor \\
\hline 27. & Ulí & Ò̀ò̀dè & Ilé & House \\
\hline 28. & Eèrù & Ebo & Ebo & Sacrifices \\
\hline 29. & Ojú & Ihò & Ihò & Holes \\
\hline 30. & Ògàgó & Àjàgbó & Orin İbílẹ̀ & Traditional Song \\
\hline 31. & Ėsíkìrí & Òsíkìrí & Òlèlè & Hard beans cake \\
\hline 32. & İsòbò & Sìgá & Sìgá & Cigarette \\
\hline 33. & Àpòlákùta & Òmóyò & Sìgá & Spicy Soup \\
\hline 34. & Alágèrẹmùsá & Òwú Aláǹtakùn & Òwú Aláǹtakùn & Cob web \\
\hline 35. & İńrún & Eérú & Eérú & Ashes \\
\hline 36. & Omi kòótó & Omi mímu & Omi mímu & Drinking water \\
\hline 37. & Tása & Àwo & Àwo & Glass Plate \\
\hline 38. & Àyègbè & Glass & Díngí & Mirror \\
\hline 39. & Ìkótí & Ìlarun & Ìlarun & Cutting comb \\
\hline 40. & Erè & Ėwà & Ėwà/Erèé & Beans \\
\hline 41. & Àyẹ & Obè & Obè & Soup \\
\hline 42. & Bìlísì & İjògbọn & Wàhálà & Trouble \\
\hline 43. & Èké & Áńgà & Áńgà & Hanger \\
\hline 44. & Ògòdọn & Àdá & Àdá & Cutlass \\
\hline 45. & Ìkè̀lù & Síbí & Síbí & Spoon \\
\hline 46. & Àmúga & Sísốòsì & Sísốòsì & Scissors \\
\hline 47. & Àgbékó & Àòtétélè & Àwòtẹlè & Inner Wear \\
\hline 48. & Yèrrì̀ & Síkẹè̀tì & Síkẹètìi/Yèrì & Skirt \\
\hline 49. & Àkétè & Àtú & Ate & Hat \\
\hline 50. & Àkún & İlèkè̀ & İlè̀kè & Bead \\
\hline
\end{tabular}

Some differences were observed in the way elders and youths pronounce some words in Ìkàrẹ́-Àkókó dialect. This results from substitution of sounds, addition of sounds or lexical 
change. For instance, while the elders say 'Úurùnmọ̀bà', the youths say 'Òórùnmọ̀bà'. There is replacement of $/ \mathrm{o} /$ sound for $/ \mathrm{u} /$. Other examples include: 'Alùwè' to 'Balùwè̀ with addition of /b/ sound; 'Òpọ̀tọ́' to 'Òpọ̀lọ' with /t/ sound changed to / 1/; 'Àkún changed to 'Ìlè̀kẹ̀'; 'yẹ̀rrì', 'Eéra', 'Usẹ́n', 'Ìkèlù', 'Tása', 'Àgbékọ́', changed to 'Síkẹeẹtì, 'Ewé', 'Òbe', 'Síbí', 'Àwo', 'Àwọ̀tếlè̀, etc.

Table 17: Other differences observed in the use of language by elders and youths in Ìkàrẹ́-Àkókó dialect

\begin{tabular}{|c|c|c|c|c|}
\hline $\mathbf{S} / \mathbf{N}$ & Elders & Youths & $\begin{array}{c}\text { Yorùbá } \\
\text { Equivalent }\end{array}$ & Meaning in English \\
\hline 1. & Ralẹ̀ Ibè̀yẹn & Sọ̀kalẹ̀ níbẹ̀yẹ́n & Sọkalẹ̀ níbè̀yẹn & $\begin{array}{l}\text { Step down from } \\
\text { there }\end{array}$ \\
\hline 2. & Káríyá & Káíyá & wá/ wá níbí & Come or come here \\
\hline 3. & Sí bú wẹ́ wò? & Í bí wẹ wò? & Níbo lò ń lọ? & $\begin{array}{l}\text { Where are you going } \\
\text { to? }\end{array}$ \\
\hline 4. & Kọ̀nà yẹ́ & Kọ̀nà & Tiilẹ̀kùnyẹn. & $\begin{array}{l}\text { Close that door or } \\
\text { close the door. }\end{array}$ \\
\hline 5. & Iyeodó sìré? & Odó 1 & Níboniì & $\begin{array}{l}\text { Where is the big } \\
\text { mortal? } \\
\text { Mortal). }\end{array}$ \\
\hline 6. & Òtùtà & İjokòó & İjókòó/Àpótí & $\begin{array}{l}\text { Otuta is a sit, a small } \\
\text { bench which you can } \\
\text { sit on. }\end{array}$ \\
\hline 7. & $\begin{array}{l}\text { Wò ká gbé àyẹ } \\
\text { yẹ́n ranọ́? }\end{array}$ & $\begin{array}{l}\text { Wò ká gbé obè } \\
\text { yẹnnúná? }\end{array}$ & $\begin{array}{l}\text { Sé o tigbé obẹ̀ } \\
\text { kaná? }\end{array}$ & $\begin{array}{l}\text { Have you warmed } \\
\text { the soup? }\end{array}$ \\
\hline 8. & $\begin{array}{l}\mathrm{Ru} \text { úshá } \\
\text { sánomiyẹ́n sọ̀nú. }\end{array}$ & $\begin{array}{l}\text { Rù úshá gbá } \\
\text { omiyẹ́n sọ̀nú. }\end{array}$ & $\begin{array}{l}\text { Fí ìgbálè̀ gbá } \\
\text { omiyẹnsọù. }\end{array}$ & $\begin{array}{l}\text { Use broom to sweep } \\
\text { away that water. }\end{array}$ \\
\hline 9. & Bọ ố nínú rè̀. & Ki ố nínú rè. & Ki ọwọ́ ẹ sí inú ẹ. & $\begin{array}{l}\text { Dip your hand } \\
\text { inside. }\end{array}$ \\
\hline
\end{tabular}

It was observed that the way İkàré-Àkókó youths make use of the dialect has been greatly influenced by Yorùbá language. One of the differences discovered between the use of the dialect by the elders and the youths is omission of some sounds by the youths. In some instances, the words are completely changed. For instance, the younger people use "Sọkalè níbèyẹ́n" instead of "Ralẹ Ibẹyẹ́n". The second example in Table 17 above shows omission of a consonant sound ' $r$ '. While the elder says 'Káríyá', the youths say 'Káíyá'. This also reflects in the third example in which "Sí bú wẹ́ wò?" is uttered as "Í bí wẹ́ wò?" - Omission of 's' consonant from 'si'. Example 6 on the table shows the use of Yorùbá words to replace some words in İkàré dialect. "Òtùtà" is commonly used by the elders while the youths use "İjokòó”. Also, in example 7, “... gbé àyẹ yẹ́n ranọ́” and “... gbé ọbẹ yẹnnúná”. "Àye” in Ìkàrẹ dialect means "soup" while "ranọ" means "warm on fire". These words have been substituted with 'obẹ̀' and 'núná'. In example 8 , "gbá" is used by the youths to replace "sán" for "sweep". It was further observed that loan words from English and Yorùbá exist in İkàrẹÀkókó dialect. Examples are presented below:

1. Mòo ká jẹ búrẹdì: I have eaten bread

2. Gbe ní orí tábili: Put it on the table.

3. Fáànù yẹnfẹ:: Is the fan blowing.

4. Èlú ye iìrésì rẹ: How much is your rice

5. Ago mélú yé lù; What says the time?

6. Gbá bóòlù yẹnsí mi: Pass the ball to me

7. Wèé ru síbi jế? Can you eat it with spoon?

8. Filà re sìre? Where is your cap? 
9. Wẹ̀ mẹ fọ́ àwo yẹn: You will break that plate

10. Se omi únmi ké: Get me water to drink.

The italicized words in the above constructions are either English words adapted to Yorùbá pronunciation or words used in standard Yorùbá language.

\subsection{Examples of Code-Switching in Ìkàrẹ́ Dialect}

The following are some examples of code-switching observed among the youths of Ìkàrẹ-Àkókó in their use of the dialect:

1. E E jàre ẹ bú mi print kiní ye unú flash (Please, help me to print something from this flash drive.)

2. Yagbé pot obè mi á? (Bring my pot of soup.)

3. Wọ́ ká gba certificate rẹ? (Have you collected your certificate?)

4. Ho inú wardrobe mi yẹ (Look inside my wardrobe.)

5. Mî́ kọ́ computer: (I'm learning computer.)

6. Mî́ gun machine: (I will ride motorcycle.)

7. Yàá gbé cup yẹ́n ún mi: (Go and bring me that cup)

8. Phone re shì re? (Where is your phone?)

9. Á hún mi ní coke mu? (Give me a coke to drink.)

10. Call rẹ̀ wọ ja moibẹ á. (Call him so we can know where he is.)

Being a multilingual society, there are many languages spoken in Ìkàrẹ́-Àkókó such as Yorùbá, Igbo, Ebira, Hausa and English. There are also indigenes of other neighbouring communities who speak other dialects such as Akùnù, Ikaram, Arigidi, Àjọwá, etc. In Nigeria generally, English occupies the position of an official language and is the language for wider communication. Some English words are borrowed and used directly in Ìkàrẹ-Àkókó dialect as seen in the above examples. These are words for which direct interpretations or replacements are not available in the dialect and even the standard Yorùbá language, or the people find them convenient for use. Some of these words include computer, pot, certificate, machine, phone call, cup, etc.

\section{CONCLUSION}

The findings of the study show that in Ìkàrẹ́, like many other communities in Nigeria, English has become the language of many homes. Some parents forbid their children from speaking any other language except English language. Apart from being the official language and a language of wider communication, other demographic variables that have bearing on the use of English language include education, socio-economic status and occupation. For example, the level of education determines a person's occupation and his/her socio-economic status. It was found that the people of İkàrẹ-Àkókó value education. A respondent who has been a secondary school principal in İkàrẹ for many years said that in the whole of Àkókó land, Ìkàré has the highest number of graduates both home and abroad. They believe education is a very strong key to success.

It is also obvious from the findings of this study that Yorùbá language has high prestige in İkàré-Àkókó town. This confirms what Dada (2007) and Oyetade (2005) observed that some Nigerian languages enjoy high prestige while some are held in low prestige. Majority of the respondents acquired Yorùbá as their first language and it still remains the language they speak best. Only a few speak Ìkàrẹ-Àkókó dialect fluently and these are mostly elderly people while the utterances of the youths reflect interference. This again is in line with the findings of Lenneberg (1967) and Kerswill (1994; 1996) that adults who have passed the 'critical stage' of language acquisition are not likely to be able to make major grammatical and phonological changes in their speech. It was found that many youths codeswitch to Yorùbá or English when using the dialect. It is obvious that it is not only English 
language that has dominated İkàrẹ-Àkókó dialect but the Yorùbá language has replaced it in many domains.

It was observed that the levelling of the Ìkàrẹ-Àkókó dialect is caused in part by restricted domains of use. Vital domains like home, market and school, which are supposed to be the strongholds of the dialect, are being encroached upon by other languages. Other factors associated with the levelling are increase in population due to geographical and social mobility, lack of commitment to indigenous language use and development by the native speakers and suppressive language policy in the nation. In the school setting for instance, although the National Policy on Education states that the medium of instruction in the primary schools is initially the mother-tongue or the language of the immediate community, and at a later stage, English, the practice is different. Some institutions start as from primary one or even preprimary classes to use English language in their schools and even punish a child who uses his mother tongue for self-expression at such level. Owojecho (2020, p. 277) notes that the persistent failures and shortcoming in the implementation of national language policy guidelines and procedures over the years has given prominence and undeserved recognition to English language in Nigeria.

Some changes were observed in Ìkàrẹ́-Àkókó dialect such as the replacement of some words with Yorùbá words and partial change of some words resulting from replacement of consonants and other sounds. It was found that even the elders no longer make use of some words such as 'İkẹlù', 'Tása' and 'Usẹn', but have replaced them with 'Síbi', 'Àwo' and 'Òbe' respectively. Also, there are some words borrowed from English and used by speakers of Ìkàrẹ́ dialect.

It was however observed that the attitude of Ìkàrẹ-Àkókó indigenes towards their dialect is generally positive. Many of the native speakers respect and value the dialect. The dialect is associated with high prestige among the native speakers and people who associate with them. This positive attitude demonstrated by the indigenes is an indication that serious efforts to preserve the dialect will yield positive results.

The following recommendations are made to ensure that İkàrẹ́-Àkókó dialect is preserved. One way is to encourage younger generations to speak it as they grow so that they can also teach their children. The radio, television and internet can be used to raise awareness about the necessity of preserving the dialect. The internet can also be used to translate, catalog, store, and provide information and access to this dialect. New technologies such as podcasts can also be used to preserve the spoken version.

\section{REFERENCES}

Adamson, H. D. (2009). Interlanguage Variation in Theoretical and Pedagogical Perspective, Routledge. https://www.semanticscholar.org

Ahmad M. M. (2016). Nigeria's Multilingual Setting and Critical Evaluation of the National Language Policy: Prognosis of the Future of Nigerian Languages. Journal of Education \& Social Policy, 3(4), pp.132-134. http://jespnet.com

Akindele, F and Adegbite, W. (1999). The Sociology and Politics of English in Nigeria, Ibadan: OAU Press. https://www.scirp.org/(S(i43dyn45teexjx455qlt3d2q))/reference/ ReferencesPapers.aspx?ReferenceID=1772829

Akinkurolere, S. O. and Akinfenwa, M. O. (2018). A Study on the Extinction of Indigenous Languages in Nigeria: Causes and Possible Solutions. Annals of Language and Literature, 2(1), pp.22-26. https://www.sryahwapublications.com 
Appel, R. \& P. Muysken (1987). Language Contact and Bilingualism. London: Edward Arnold. https://www.scribd.com/document/59300824/26134268-Appel-Muyskel-LanguageContact-and-Bilingualism

Bassiouney, Reem. (2008). Levelling. Encyclopaedia of Arabic Language and Linguistics, KeesVersteegh et al. (eds.), III: 8-13. Leiden-Boston, Brill. https://hal.archivesouvertes.fr/hal-00826611/document

Blair, D. and Collins, P. (2001). English in Australia. Amsterdam/Philadelphia: John Benjamins Publishing Company. https://benjamins.com/catalog/veaw.g26

Blench, R. (1998). The Status of the Languages of Central Nigeria. Brenzinger, Matthias (ed.) Endangered Languages in Africa. pp.187-205. Koln: Rudiger Koppe. https://silo.pub/an-introduction-to-african-languages.html

Chambers, J. K. (2003). Sociolinguistic Theory, 2nd ed., Polity (imprint of Blackwell Publishers) Language in Society series. https://linguistlist.org/issues/14/14-1242/

Comrie, Bernard. (ed.) (1990). Lexical Variation and Genetic Affiliation: The case of Haruai. Jerold A. Edmondson, Crawford Feagin, and Peter Muhlhausler, eds,: Development and Diversity: Linguistic Variation Across Time and Space: A Festschrift for CharlesJames N. Bailey (Summer Institute of Linguistics and the University of Texas at Arlington Publications in Linguistics, 92:461-466. Dallas: Summer Institute of Linguistic and Arlington: University of Texas at Arlington. https://glottolog.org/resource/reference/id/47785

Coupland, N. (2007). Style: Language Variation and Identity. Cambridge University Press.

Crystal, David. (2000). Language Death. Cambridge: Cambridge University Press.

David, Lee (1986). Language, Children and Society: An Introduction to Linguistic and Language Development. London. The Harvest Press. https://www.amazon.com/Language-Children-Society-IntroductionDevelopment/dp/0814750257

Dada, S.A (2007). Language Attitude in Erushu Akoko. Journal of Language, Culture and Communication, 1(4\&5), pp.1-15.

Dillard, J. L. (1972). Black English: Its History and Usage in the United States. New York: Random House. 4(2).

Dittmar, N. (1976). Sociolinguistics: A Critical Survey of Theory and Application. London Arnold Press. https://doi.org/10.1177\%2F003368827901000213

Ejele, P. E. (2002). Language Use in a Multilingual Society: An Update on the Nigerian Situation. Okon, M. and O. E. Essien (Eds.) Topical Issues in Sociolinguistics: The Nigerian Perspective. Aba: National Institute for Nigerian Languages, pp.43-52.

Emenanjo, E. N. (1985). Nigerian Language Policy: Perspective and Prospective. Journal of the Linguistic Association of Nigeria. 3, pp.123-134. https://academicjournals.org/journal/IJEL/article-references/6DAC8A162804

Fakuade, A. G. (1995). Language Contact and Language Conflict: The Kuteb-Jukun Case in Taraba State, Nigeria. A PhD thesis submitted to the Department of Linguistics and Nigerian Languages, University of Ilorin.

Fakuade, G. (2001). "Language Endangerment in the North-East Nigeria: Instances and Strategies for Averting it'. Annals of Borno 113(1)4, pp.41-48. 
Fakuade, G., M. Gambo \& A. Bashir (2003). Language Shift from Mother Tongues towards Fulfulde in Adamawa State, Nigeria: Causes and Consequences. Anthropological Linguistics, 45(3), pp.296-315. https://glottolog.org/resource/reference/id/111975

Fasold, R. (1984). The Sociolinguistics of Society. Oxford: Oxford University Press.

Halliday, Michael. A. K. (1978). Language as Social Semiotic: The Social Interpretation of Language and Meaning. London: Edward Arnold..De: Https://www.Due.De/ELE.

Hickey, R. (2010). Language Variation and Change. Https://www.uni-due.de.

Hinskens, Frans. (Eds.) (1996). Dialect levelling in Limburg: Structural and sociolinguistic aspects. Linguistische Arbeiten.

Hinskens, Frans. 1998. Dialect Levelling: A Two-dimensional Process. Folia Linguistica 32(1-2), pp.35-52.

Kerswill, Paul (2001). Mobility, Meritocracy and Dialect Levelling: The Fading (and phasing) out of Received Pronunciation. British Studies in the New Millennium: The Challenge of the Grassroots. University of Tartu, Tartu.

Kerswill, Paul E. (1994). Dialects Converging: Rural speech in urban Norway. Oxford: OUP.

Kerswill, Paul. and Trudgill P. (2005). The Birth of New Dialects. Dialect Change, Convergence and Divergence in European Languages, Peter Auer / Frans Hinskens / Paul Kerswill (eds.), pp.196-220. Cambridge: Cambridge University Press.

Labov, W. (1963). The social motivation of a sound change. Word, 19:273-309.

Labov, W. (1972a). Language the Inner City. Philadelphia: University of Pennsylvania Press.

Labov, W. (1972b). Sociolinguistic Patterns. Oxford: Basil Blackwell.

Lefebvre, C. (1998). Creole genesis and the acquisition of grammar: The case of Haitian creole. Cambridge, UK: Cambridge University Press.

Lenneberg, E. H. (1967). Biological Foundations of Language. New York: John Wiley \& Sons.

Preston, Dennis R. (1993). "Variation linguistics and SLA". Second Language Research. 9 (2): 153-172.

Munkaila, M. and A. Haruna (2001). Motivations and Attitude: the case of German students learning Hausa Language. Igboanusi, H. (Ed.) Language Attitude and language Conflict in West Africa, pp. 45-59.

Olumuyiwa, T. and Oshodi, B. (2012). On the linguistic situation in Àkókó. Carlifornia Linguistic Note. 37(1), pp.1-8.

Otite, O. (1990). Ethnic Pluralism and Ethnicity in Nigeria. Ibadan: Shane \& Sons Ltd.

Owojecho, F. A. (2020). Implementation challenges of national language policy in Nigeria: The roles of the indigenous languages. International journal of language and literary studies, 2(1), pp.270-279. https://doi.org/10.36892/ijlls.v2i1.183

Oyetade, S.O. (2005). Incipient Language Shift in Auga, Akoko. Journal of Language, Culture and Communication, 4 \& 5 pp. 1-15.

Siegel, Jeff. 1997. Mixing, Levelling and pidgin/creole development. A. Spears and D. Winford (eds.), The structure and status of pidgins and creoles. Amsterdam: John Benjamins, 111-49. 
Trudell, Barbara. (2019). Language and Education in Nigeria: A Review of Policy and Practice. British Council. https://www.academia.edu/41464563/ Language and_education

Trudgill, P. (1986) Dialects in Contact. Oxford: Basil Blackwell.

Ugwuoke, I. (1999). Nigerian Languages in Danger of Disappearing. Emenanjo, E.N and P.K. Bleambo (eds.) Language Endangerment and Language Empowerment in Nigeria: Theory and Reality. 1, pp. 14-31.

Wardhaugh, R. (2010). An Introduction to Sociolinguistics. $6^{\text {th }}$ ed. Malden, MA: WileyBlackwell. https://www.academia.edu/31761449/An_Introduction_to_Sociolinguistics

Williams, A. and Kerswill, P. (1999). Dialect Levelling: Change and Continuity in Milton Keynes, Reading and Hull. P. Foulkes and G Doherty (eds.) Urban Voices: Accent Studies in the British Isles. London: Arnold. 141-162. https://citeseerx.ist.psu.edu/viewdoc/download?doi=10.1.1.693.7923\&rep=rep1\&type=pdf

Williamson, K. \& Blench, R. (2000) Niger-Congo. African Languages: An Introduction. Cambridge University Press.

Ondo State, Nigeria. Retrieved on March 3, 2021 from http://en.m.wikipedia.org.

Yunusa, A. (2020) Nigerian Languages Going into Extinction. Premium Times, 8 September 2020. $\quad$ https://guardian.ng/news/nigerian-languages-going-into-extinction-nico/ Downloaded 22 October 2020.

\section{$\underline{A U T H O R S^{\prime} B I O}$}

Esther Olayinka Bamigbola is a senior lecturer in the Department of English Studies, Adekunle Ajasin University, Akungba-Akoko, Ondo State, Nigeria. Her research areas include pragmatics, sociolinguistics, applied linguistics, semantics, discourse analysis and bilingualism. She is personally interested in the development of curricular and extracurricular activities for an enhanced English-speaking and writing culture.

Fadekemi Rukayat Umar is a Graduate student in the Department of English Studies, Adekunle Ajasin University, Akungba-Akoko, Ondo State, Nigeria. 


\section{APPENDIX}

\section{QUESTIONNAIRE}

\section{SECTION A}

1. Age: $10-20$

$21-40$

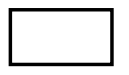
$41-60$<smiles>C1CCC1</smiles>
61 and above

2. Sex: Male

Female

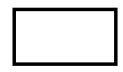

3. Place of Birth: Town:

4. Local Government Area: State of Origin:

5. Tribe

6. Educational qualifications:
(a) Primary
(b) Secondary
$+$
(c) Tertiary Institution
(d) NCE/OND
(e) First Degree/HND
(f) Master
(g) $\mathrm{PhD}$

7. Occupation:

\section{SECTION B}

8. What language did you first acquire as a child?

9. (a) Can you still speak the language you first spoke as a child? Yes

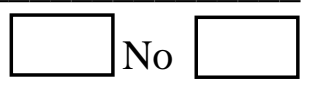

(b)Is this still the language you speak best? (a) Yes

(b) No

(c) If no, (a) what language(s) do you speak better?

10. What other language(s), if any, do you speak well now?
(a)
(b)
(c)
(d)

11. (i) Of these languages that you understand and speak, which do you use frequently?

(a)

(b)

(c)

(d)

(ii) Apart from those already mentioned, which other language(s) do you understand and use less frequently?

(a) 
(b)

(i) Can you read? Yes

No

(ii) If yes, what language(s) can you read?

(a)

(b)

(c)

(d)

(iii) What kind of materials do you read in each of these languages?

Language (a) Letters (b) Notices (c) Newspapers (d) Textbooks (e) Story Books

English

Yorùbá

Igbo
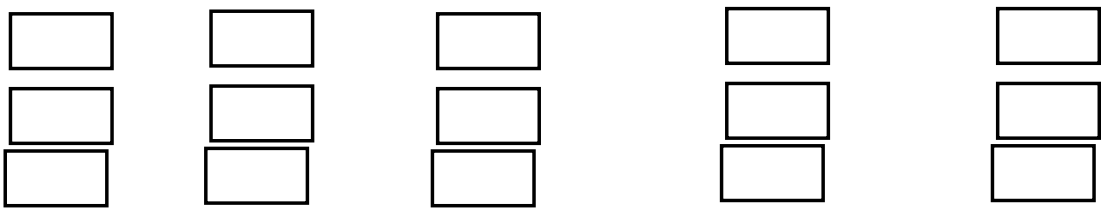

Hausa

French

Any Other:

12. (i) Can you write? Yes
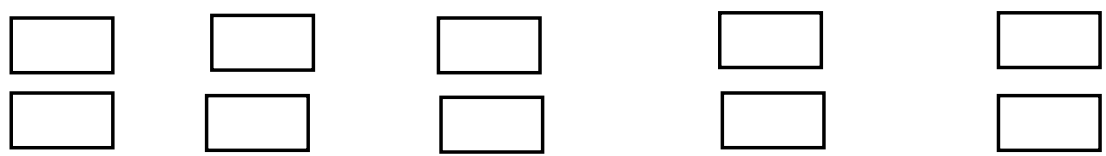

(ii) If yes, what language(s) do you write?

(a)

(b)

(c)

(d)

(iii) What type of documents do you write in these languages?

Language (a) Letters (b) Notices (c) Reports (d) Books (e) Others

English
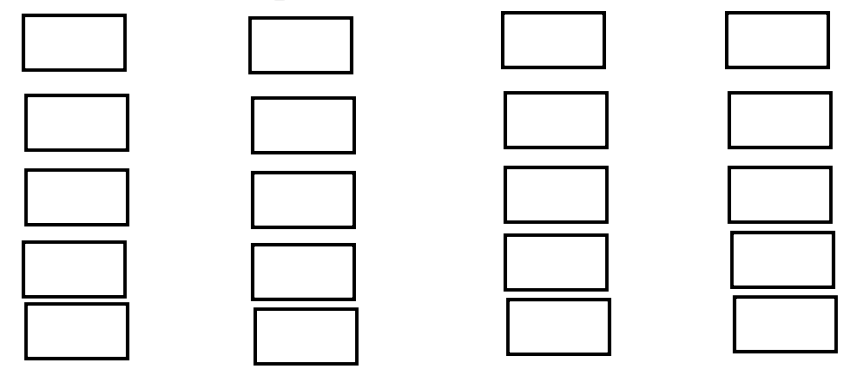

13. (i) What language(s) do you speak at home?

(a) To your wife or husband?

(b) To your parents?

(c) To your children?

(d) To your friends?

(e) To your brothers and sisters? 
(ii) What language(s) do you speak at work?

(a) To your employer?

(b) To your subordinates?

(c) To your equals?

(d) To your customers?

14. (i) Is there any place apart from your home and your place of work where you spend much time? Yes $\square$ No $\square$

(ii) If yes, for what purpose?

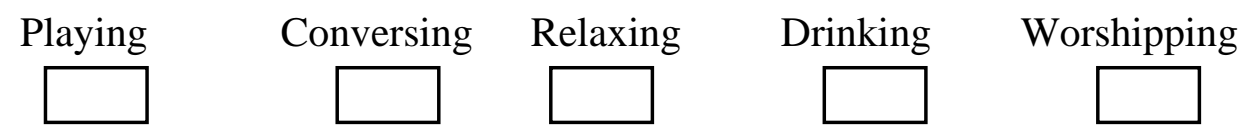

(iii) If so, please name the place(s) and the language(s) you use there.
Place
Language(s)

(a)

(b)

(c)

(d)

\section{SECTION C}

15. (i) Is there any language you do not understand/speak but which you would like to learn? Yes $\square$ No $\square$

(ii) If so, which language(s) and why?

Language

Reason

(a)

(b)

(c)

(d)

16. (i) Is there any language you use and would like to be more competent in?

Yes

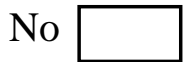

(ii) If so, what language(s) and why?

Language

Reason

(a)

(b)

(c)

(d) 
17. (i) Is there any language you speak but you would not like to speak again? Yes No

(ii) If so, why?

Language

Reason

(a)

(b)

(c)

(d)

18. (i) Is there any language you do not speak and would not like to learn even if you have the opportunity to learn it? Yes

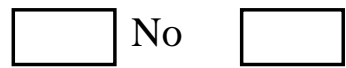

(ii) If so, what language?

Language

Reason

(a)

(b)

(c)

(d)

19. (i) Is there any language you would not like your children to learn?

Yes

No

(ii) If so, what language?

Language

Reason

(a)

(b)

(c)

(d)

20. What do you think will be the main language to be used in the future in:
(a) Your community?
(b) Your local government? 